\title{
Occupational advice from vocational counselors for adults who stutter and associated factors*
}

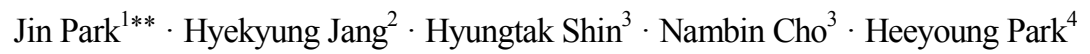 \\ ${ }^{1}$ Department of Speech, Rehabilitation, Counseling, Catholic Kwandong University, Gangneung, Korea \\ ${ }^{2}$ Graduate Program of Speech-Language Pathology, Chungnam National University, Daejeon, Korea \\ ${ }^{3}$ Graduate Program of Speech-language Pathology, Yonsei University, Seoul, Korea \\ ${ }^{4}$ Department of Communication Disorders, Ewha Womans University, Seoul, Korea
}

\begin{abstract}
This study aimed to primarily examine perceptions about occupational suitability made by vocational counselors for adults who stutter and associated factors. A total of 69 vocational counsellors ( 23 per condition) took part in this study and were randomly assigned to recordings related to three different speech conditions (fluent, less-severe stuttering, and severe stuttering versions). The participants were asked to listen to one of the three recordings and rate the speaker's communicative functioning, personal attributes, and suitability for 31 occupations, along with perceptions of the speaking demands and educational requirements of the occupations. Regarding the two stuttering conditions, it was found that suitability ratings were lower for occupations with a high speaking demand than those with a low speaking demand. In addition, the most significant factor associated with occupational suitability ratings was perceived speaking demands, followed by perceived educational requirements, and then by ratings of the speaker's personal attributes. These findings suggest that adults who stutter may face role entrapment (or occupational stereotyping) in workplace settings.
\end{abstract}

Keywords: stuttering, occupational advice, vocational counsellor, role entrapment

\section{1. 서론}

유창성장애는 말의 흐름이 자연스럽지 않은 것을 말하며 말 더듬이 대표적이다(Lee, 2010; Van Riper, 1982). 말더듬은 세 가 지 관련 행동으로 나누어 정의될 수 있는데(Wingate, 1964), 첫째
는 구어 표현에서 나타나는 유창성 단절로 짧은 말의 구성요소 즉, 말소리, 음절, 단어의 불수의적인 반복이나 말소리 연장과 막힘 등의 비운율적 발성이 자주 발생하거나 눈에 띄며 쉽게 통 제되지 않는 것을 말한다. 둘째로 때때로 말 기관과 연관된 (또 는 연관되지 않은) 신체구조가 관여된 부수행동인 일명 탈출행

\footnotetext{
* This work was supported by the Ministry of Education of the Republic of Korea and the National Research Foundation of Korea (NRF-2017S1A5A8018870). We are grateful to all of the vocational counselors with whom we have had the pleasure to work during this project.

** gatorade70@cku.ac.kr, Corresponding author

Received 1 May 2019; Revised 30 May 2019; Accepted 11 June 2019

(c) Copyright 2019 Korean Society of Speech Sciences. This is an Open-Access article distributed under the terms of the Creative Commons Attribution NonCommercial License (http://creativecommons.org/licenses/by-nc/4.0) which permits unrestricted non-commercial use, distribution, and reproduction in any medium, provided the original work is properly cited.
} 
동(예를 들어, 혀로 입술 핱기, 머리를 뒤로 젖히기, 손바닥으로 무릎치기)을 동반하기도 한다. 셋째로 자주 흥분과 긴장된 감정 상태에서부터 부끄러움이나 두려움, 공포와 같은 구체적이고 부정적인 감정 상태가 나타난다. 이러한 관련 행동들로 인한 수 치심, 좌절감, 죄의식 등으로 자신에 대한 부정적 생각이나 느 낌, 태도를 갖게 되면서 결국 개인과 사회생활에 지대한 영향을 미치는 장애가 바로 말더듬이다.

본 연구에서는 이러한 말더듬이 개인과 사회생활에 미치는 여러 영향 가운데, 특히 (말더듬이) 말더듬 성인에 대한 직업 추 천에 어떠한 영향을 미치는지를 알아보고자 하였다. 현재까지 말더듬 성인들에 대한 직업 관련 인식이나 추천 양상에 대한 연 구들은 주로 미국을 중심으로 해외에서 행해져 왔다(Gabel et al., 2004; Hurst \& Cooper, 1983b; Hurst \& Cooper, 1983a; Klein \& Hood, 2004; Logan \& O'Connor, 2012). 예를 들어, 실제로 말을 더듬는 사람들을 경험한 고용주 644명을 대상으로 한 Hurst \& Cooper(1983b)의 연구에서는 $85 \%$ 의 고용주가 말더듬이 취업에 부정적인 영향을 미칠 뿐 아니라 승진에도 걸림돌이 될 수 있다 고 답하였다. 또한 응답자의 $30 \%$ 가 말더듬이 전반적인 직업 수 행에 부정적인 영향을 미칠 것으로 보았다. 이러한 '말의 문제, 로 인해 $44 \%$ 는 말더듬 성인이 비교적 말(능력)이 크게 요구되지 않은 직업을 선택하는 것이 낫다고 답하였다. 152 명의 직업상담 사를 대상으로 한 후속연구(Hurst \& Cooper, 1983a)에서도 응답 자의 $78 \%$ 가 말더듬이 취업에 실제적인 걸림돌로 작용할 수 있 는 매우 심각한 장애 중 하나라고 답하였다. 더 나아가 232명의 말더듬 성인을 대상으로 한 Klein \& $\operatorname{Hood}(2004)$ 의 연구에서는 응답자의 $70 \%$ 가 말더듬이 취업이나 승진에 부정적인 영향을 미 친다고 답하였으며, $40 \%$ 는 만약 말을 더듬지 않았다면 다른 직 업을 선택하였을 것이라고 답하였다. 결국 직업과 관련해 말더 듬에 대한 고용주나 직업상담사의 부정적인 인식이 실제 말을 더듬는 사람들에게도 비교적 일관적으로 나타나고 있음을 알 수 있다.

직업과 관련해 말더듬 성인들에 대한 전반적인 인식 현황을 넘어 구체적으로 이들에게 어떤 직업(들)이 적절한지에 대한 연 구들도 진행되었다. 예를 들어, Gabel et al.(2004)은 385명의 대 학생들을 대상으로 직업조언척도(VAS, vocational advice scale) 를 이용해 총 43 개의 개별 직업에 대해 말더듬 성인에 대한 추천 정도(1은 ‘전혀 추천 안함’, 5 는 ‘매우 추천함’)를 조사하였다. 연 구결과, 일반화자보다 20개 직업(예를 들어, 변호사, 판사, 언어 치료사, 목사)에서 유의하게 평균점수가 낮게 나타났는데, 결국 '말의 문제'를 가지고 있는 말더듬 성인들에게는 상대적으로 말 (능력)이 크게 요구되는 직업에 대한 추천 정도가 낮게 나타난 결과라 할 수 있다.

더 나아가 Logan \& O'Connor(2012)는 단순히 말더듬 성인들에 대한 개별 직업의 추천 양상뿐 아니라 이러한 직업 추천에 있어 유의하게 영향을 미치는 요인들이 무엇인지에 대해 규명하는 연구를 실시하였다. 구체적으로, 이들은 116 명의 대학생들을 대 상으로 미국 고용노동부의 직업전망서(2006 2007년)에 기재된 직업목록에서 직업 관련 말하기 요구량 정도(즉, 특정 직업에서
요구되는 말하기 요구량 정도)와 직업 관련 교육 수준 정도(즉, 특정 직업에서 요구되는 교육 수준 정도)의 차이를 바탕으로 총 32 개의 직업을 선정하였다. 그리고 말더듬 정도에 차이가 있는 말더듬 성인의 발화샘플(심한(severe) 말더듬과 덜 심한 (less-severe) 말더듬) 또는 일반화자의 발화샘플(유창한(fluent) 발화)을 들려주고 실험참가자들로 하여금 각 직업에 대한 추 천 정도를 표시하도록 하였다. 또한 의사소통능력이나 의미 차 이(협조적인, 대담한과 같은 행동적 특성)와 같은 화자의 내적 (intrinsic) 특성에 대한 (인상) 평정을 추가해 이러한 요인들이 직업 추천에 어느 정도 영향을 미치는지도 조사하였다. 연구 결 과, 말더듬 성인의 경우 말더듬의 심함 정도에 상관없이(즉, 심 한 말더듬과 덜 심한 말더듬의 모든 경우에서) 상대적으로 말하 기 요구량 정도가 낮은 직업(예를 들어, 자동차부품 조립원, 용 접원, 집배원)을 더 높게 추천하는 것으로 나타났다. 반면, 일반 화자의 경우에는 교육수준이 높은 직업(예를 들어, 연구원, 컴 퓨터프로그래머, 교사)을 더 높게 추천하는 것으로 나타났다. 직업 추천 정도와 관련해 말더듬의 경우에는 직업 관련 말하기 요구량 정도가, 일반화자인 경우에는 직업 관련 교육 수준 정도 가 더 높은 상관관계를 보였다. 또한 말더듬의 경우에는 직업 추천 정도와 관련해 의사소통능력이나 의미 차이 평정이 유의 한 상관관계를 보이지 않았으나, 일반화자인 경우에는 유의한 상관관계를 보였다. 이는 이전 연구(Gabel et al., 2004)에서 말을 더듬는 사람들에게 직업 관련 말하기 요구량이 낮은 직업을 더 높게 추천한다는 직업 추천의 제한성(role entrapment)을 동일하 게 보여주는 결과이다.

본 연구를 계획하게 된 목적은 첫째, 앞서 언급한 바와 같이 말더듬 성인에 대한 직업 관련 연구들이 주로 미국과 같은 해외 에서 행해져 왔다. 말을 더듬는 사람에 대한 인식 정도와 관련해 또는 직업의 유형과 성격에 있어 사회, 문화적 차이가 존재할 수 있기에(Shim, 2000) 국내 상황에 더 적합한 말더듬 성인에 대한 직업 추천 양상 연구가 필요하다고 본다. 둘째, 본 연구에서는 한국 고용노동부에 기재된 직업목록을 바탕으로 일반인이 아 닌 직업상담사를 대상으로 말더듬 성인에 대한 직업 추천 양상 과 관련 요인들에 대한 연구를 진행하였다. 직업상담사는 주로 직업안정기관이나 교육훈련기관, 인력관련기관, 기업의 상담 실, 초·중·고등학교 및 대학교 등에서 직업선택, 취업처 결정, 직 업전환, 직업적응, 실업위기, 은퇴 등의 과정에서 내담자의 개인 적 특성을 평가하고 적합한 직업의 종류, 준비 전략 등을 조언 하여 개인으로 하여금 의사결정을 하는데 도움을 주고 직업생 활상의 문제를 예방하고 처치하는 등의 상담활동을 수행하는 전문가를 의미한다. 특히, 4 차 산업혁명으로 일컬어지는 급격한 기술의 발달과 100 세 시대로 표현되는 수명의 연장 등 제반 환 경의 변화로 인해 한 사람이 평생 6 7개의 직업을 가질 것이라 는 ‘평생 직업’이라는 개념이 강조되는 요즘(Yoo, 2017) 대상자 들을 직접 만나 고용 관련 서비스를 제공하는 직업상담사의 역 할은 더욱 중요시되고 있다고 말할 수 있다. 따라서 직업 추천 및 관련 상담 전문가로서 직업상담사를 대상으로 한 연구는 말 더듬 성인에게 상대적으로 높은 또는 낮은 추천 정도를 보이는 
직업군의 양상은 물론 이에 유의하게 영향을 미치는 요인들이 무엇인지 좀 더 실제적으로 규명해줄 수 있을 것으로 사료된다. 셋째, 가상화자가 아닌 말더듬 성인의 실제 발화 샘플을 이용한 Logan \& O'Connor(2012)에서는 말더듬의 심함 정도에 있어 두 가지 버전(심함과 덜 심함)을 통해 연구를 진행하였다. 그러나 두 발화샘플은 말더듬 중증도 검사(SSI-3, Riley, 1994)의 읽기과 제 점수표에 의하면 7점 $(\% \mathrm{SS}=.47)$ 과 8 점 $(\% \mathrm{SS}=16.32)$ 으로 비교 적 말더듬 비율의 차이가 크지 않다. 따라서 본 연구에서는 말더 듬 비율에 있어 좀 더 차이가 두드러진 두 개의 말더듬 발화샘 플과 함께 말더듬이 없어 상대적으로 유창하게 들리는 발화샘 플을 추가적으로 생성해 발화의 유창성 정도에 따라 추천하는 직업 양상이 어떻게 달라지는지 그리고 이러한 직업 추천 정도 에 유의하게 영향을 미치는 요인들이 무엇인지에 대해 조사하 고자 하였다.

본 연구의 질문은 다음과 같다. 첫째, 말더듬 성인의 발화 유 창함(심한 정도)에 따라(유창한 발화, 덜 심한 말더듬, 심한 말더 듬) 직업상담사가 추천하는 직업의 양상과 정도에 유의한 차이 가 나타나는가? 둘째, 직업 추천에 있어 직업 관련 말하기 요구 량 정도와 직업 관련 교육 수준 정도는 유의한 상관관계를 보이 는가? 셋째, 말더듬 성인의 발화 유창함(심한 정도)에 따라 직업 상담사의 의사소통 평정과 의미 차이 평정(행동적 특성에 대한 인상)에 있어 유의한 차이가 나타나는가? 마지막으로 직업 추 천에 있어 의사소통 평정과 의미 차이 평정은 유의한 상관관계 를 보이는가?

\section{2. 연구방법}

\section{1. 연구대상}

총 69명의 직업상담사를 세 가지 발화상황(유창한 발화, 덜 심한 말더듬, 심한 말더듬)에 따라 각각 23 명을 무작위로 배정 하여 실험을 수행하였다. 연구대상자는 유관기관(예를 들어, 한 국직업상담사협회, 직업상담사협동조합)을 통한 협력과 공지, 그리고 시, 군, 구청의 취업정보(지원)센터, 여성인력개발센터, 또는 대학교의 취업정보센터 등에 근무하는 직업상담사들을 대상으로 홍보하거나 이들을 통해 관심이 있는 다른 직업상담 사들에게 구두로 알리는 방식으로 모집하였다.

대상자의 선정 기준은 다음과 같다. 모국어로 한국어를 사용 해야 하며, 심리적, 정서적, 신경학적으로 실험수행에 부정적인 영향을 줄 수 있는 병력을 가지고 있지 않아야 하며, 정상적인 청력과 시력을 가지고 있어야 하며, 언어장애나 말장애와 관련 해 평가나 치료 경험이 없어야 하며, 국가공인 2 급 직업상담사 자격증을 소지한 자로 최소 1 년 이상 직업상담 관련 업무 경험 을 가지고 있어야 한다. 마지막으로 말더듬에 대한 전문지식이 나 말을 더듬는 사람에 대한 개인적 경험(1개월 이상)이 없어야 한다. 실험조건 간 연령 $[F(2,69)=1.286, p=.283]$ 과 성비 $\left(X^{2}(2)=3.715\right.$, $p=.156)$, 평균 업무 경력 $[F(2,69)=.285, p=.753]$ 에 있어 모두 유의 한 차이는 나타나지 않았다. 표 1에서는 대상자들에 대한 기본 정보를 보여주고 있다.
표 1. 실험대상자 기본정보(연령, 성별, 평균업무월수) Table 1. Characteristics of participants(age, gender, mean of working experiences)

\begin{tabular}{c|c|c|c}
\hline & 유창한 버전 & 덜 심한 말더듬 & 심한 말더듬 \\
\hline 대상자수 & 23 & 23 & 23 \\
\hline 평균연령(SD) & $39.17(8.17)$ & $40.57(7.24)$ & $36.78(8.77)$ \\
\hline 성별 & $\begin{array}{c}\text { 남자 1 } \\
\text { 여자 22 }\end{array}$ & 여자 23 & $\begin{array}{c}\text { 남자 3 } \\
\text { 여자 20 }\end{array}$ \\
\hline 평균업무 월수(SD) & $47.91(28.15)$ & $40.61(29.00)$ & $41.65(46.38)$ \\
\hline
\end{tabular}

\section{2. 발화샘플}

본 연구에 사용된 발화샘플은 다음과 같은 방식으로 생성하 였다. 구체적으로, 말더듬 성인(33세의 남성)이 '가을 문단'(Kim, 1996)을 각각 세 가지 버전(즉, 유창한 발화, 덜 심한 말더듬, 심 한 말더듬)으로 읽도록 하였다. 유창성증진상황으로서 읽기상 황에서 말더듬이 유의하게 감소하거나 또는 전혀 나타나지 않 을 수 있다는 점을 고려해(Bloodstein \& Bernstein Ratner, 2008; Park et al., 2015) 실제로 읽기상황에서 말더듬이 거의 나타나지 않아 (비교적 유창한) 말더듬 성인을 통해 유창한 발화를, 동일 한 화자를 통해 덜 심한 말더듬과 심한 말더듬은 각각 의도적 말더듬'(voluntary stuttering, Van Riper, 1982) 방식으로 생성하였 다. 본 연구에서는 기본적으로 말더듬 성인의 발화 유창성 정도 (심한 정도)에 따른 직업 추천 양상의 변화를 알아보고자 발화 유창성 이외의 다른 변수들, 즉 화자의 외모, 얼굴표정, 몸동작 등과 같은 시각적 인상 등이 실험 결과에 미칠 수 있는 영향력 을 제거하고자 음성샘플을 사용하였으며, 동시에 사람 간의 음 의 높낮이, 어조, 억양 등을 통해 드러나는 음성 특성상의 다양 성을 고려해 각 발화 조건에서 다른 화자가 아닌 동일한 화자의 음성을 녹음해 실험에 사용하였다. 파라다이스 유창성검사 II(P-FA-II, Shim et al., 2010)를 통해 말더듬 성인의 중증도를 검 사한 결과, '약함' (백분위점수 $=21 ~ 30 \%$ ile)으로 나타났다. 문단 자극은 방음 처리된 대학음성실험실에서 마이크(ECM-PC60)와 사운드 블라스터(X-FI Surround 5.1 USB)를 통해 녹음하였다. '가을 문단'은 총 369음절수이며, 말더듬 빈도(횟수)와 비율(\%SS) 은 각각 유창한 발화 0 회 $(0 \%)$, 덜 심한 말더듬 15 회(4.06\%), 심한 말더듬 78회(21.1\%)였다. 두 말더듬 버전(즉, 덜 심한 말더듬과 심한 말더듬)은 말더듬 중증도 검사(SSI-3, Riley, 1994)의 읽기 과제 점수표에 의하면 각각 5점과 9점에 해당된다. 또한 말더듬 지속시간(즉, 가장 긴 말더듬 순간 3 개의 평균)은 덜 심한 말더 듬은 0.98 초, 심한 말더듬은 3.15 초로 말더듬 길이 점수표에 따 르면 각각 4점과 10점에 해당된다. 이는 Logan \& O'Connor(2012) 의 연구에서 사용된 두 발화의 말더듬지속시간(덜 심한 말더듬 $=0.39$ 초(2점), 심한 말더듬 $=1.32$ 초(6점))과 비교해 볼 때도 좀 더 차이가 뚜렷한 음성샘플이라 할 수 있다. 말더듬 유형의 빈도로 는 덜 심한 말더듬과 심한 말더듬에서 모두 막힘, 반복, (말소리) 연장 순이었으며(Jeon \& Jeon, 2015), 말속도(전반적 말속도로 초당발화음절수)는 유창한 발화는 4.27, 덜 심한 말더듬은 3.51 , 심한 말더듬은 2.30 이었다. 또한 9점 척도(1점은 ‘매우 부자연스 러움', 9점은 ‘매우 자연스러움', Ingham et al., 2006)를 이용해 말 더듬 성인의 유창한 발화의 자연스러움(naturalness) 정도를 평 
가하였다. 이를 위해 본 연구의 목적을 인지하고 있지 않은 10 명 의 언어재활사(모두 2급 자격 소지자)가 참여하였으며 평균 7.9 점으로 말더듬 성인의 유창한 발화의 자연스러움 정도에 있어 전반적으로 문제가 없음을 보여주었다. 말더듬 빈도(비율)에 있 어 덜 심한 말더듬과 심한 말더듬의 타당도 검증을 위해 수년간 유창성장애의 임상경험을 가지고 있는 2 명의 1 급 언어재활사가 말더듬 빈도(비율)를 측정하였다. 측정 결과, 유창한 발화에서 는 $100 \%$, 덜 심한 말더듬에서는 $93.33 \%$, 심한 말더듬에서는 $97.43 \%$ 의 일치율을 보였다.

\section{3. 측정도구}

\subsection{1. 직업목록선정}

한국직업전망서(Korea Employment Information Service, 2015) 에서 제시한 총 191 개 직업들 가운데 일상생활에서 비교적 자주 접할 수 있어 친숙한 직업 88개를 선별하였다. 그리고 선별한 직 업에 대해 대학생 33 명을 대상으로 직업 관련 교육 수준 정도 (즉, 특정 직업에서 요구되는 교육 수준에 대한 인식 정도)와 말 하기 요구량 정도(즉, 특정 직업에서의 요구되는 말하기 요구량 에 대한 인식 정도)에 대한 설문조사를 실시하였다. 두 가지 척 도를 사용하여 최종적으로 평균 차이는 큰 반면 표준편차는 작 은 31 개의 직업목록을 선정하고 이들 직업을 상대적으로 구별 이 용이한 4 개의 직업군으로 다시 분류하였다. 구체적으로, 직 업 관련 교육 수준과 말하기 요구량 정도가 모두 높은 직업군, 직업 관련 교육 수준은 높지만 말하기 요구량은 낮은 직업군, 직업 관련 교육 수준은 낮은 반면 말하기 요구량은 높은 직업군, 마지막으로 직업 관련 교육 수준과 말하기 요구량이 모두 낮은 직업군이다. 표 2에서 4 개의 직업군을 보여주고 있다.

표 2. 직업 관련 교육 수준 정도와 말하기 요구량에 따른 직업군 Table 2. List of occupations classified by perceptions of educational requirements and speaking demands

\begin{tabular}{|c|c|}
\hline 분류 & 직업 \\
\hline $\begin{array}{c}\text { 직업 관련 교육 수준 정도와 } \\
\text { 말하기 요구량이 모두 높은 } \\
\text { 직업군 }(\mathrm{N}=8)\end{array}$ & $\begin{array}{l}\text { 기업고위임원(CEO), 증권 및 외 } \\
\text { 환딜러, 대학교수, 초등학교 교 } \\
\text { 사, 변호사, 상담전문가, 통역사, } \\
\text { 아나운서 }\end{array}$ \\
\hline $\begin{array}{c}\text { 직업 관련 교육 수준 정도는 } \\
\text { 높지만 말하기 요구량이 } \\
\text { 낮은 직업군 }(\mathrm{N}=7)\end{array}$ & $\begin{array}{l}\text { 연구원, 항공기조종사, 항해사, } \\
\text { 건축가, 측량전문가, 네트워크시 } \\
\text { 스템개발자, 소프트 웨어개발자 }\end{array}$ \\
\hline $\begin{array}{c}\text { 직업 관련 교육 수준 정도는 } \\
\text { 낮은 반면 말하기 요구량은 } \\
\text { 높은 직업군 }(\mathrm{N}=7)\end{array}$ & $\begin{array}{l}\text { 안내 및 접수사무원, 보험관련영 } \\
\text { 업원, 배우, 텔레마케터, 홍보도 } \\
\text { 우미, 스포츠 및 레크레이션 강 } \\
\text { 사, 결혼상담원 }\end{array}$ \\
\hline $\begin{array}{c}\text { 직업 관련 교육 수준 정도와 } \\
\text { 말하기 요구량이 모두 낮은 } \\
\text { 직업군 }(\mathrm{N}=9)\end{array}$ & $\begin{array}{l}\text { 애완동물미용사, 연예인 매니저, } \\
\text { 화물차운전원, 택배원, 경비원, } \\
\text { 도배공, 어업관련종사자, 용접원, } \\
\text { 자동차부품조립원 }\end{array}$ \\
\hline
\end{tabular}

\subsection{2. 평정 척도}

본 연구에서는 직업과 관련된 세 가지 평정 척도를 사용하였 다. 구체적으로, 특정 직업과 관련해 이 직업에서의 말하기 요구 량에 대한 인식 정도를 평정하는 말하기 요구량 척도(speaking demands scale)'와 특정 직업에서 요구되는 교육 수준에 대한 인식 정도를 평정하는 '교육 수준 척도(educational requirements scale)' 그리고 특정 직업에 대한 추천 정도를 평정하는 '직업 조언 척 도(occupational advice scale)'이다. 모두 5점 척도(1점은 ‘매우 낮 음', 5점은 ‘매우 높음’)이며, 말하기 요구량 척도와 교육 수준 척 도는 Logan \& O'Connor(2012)를, 직업 조언 척도는 Gabel et al.(2004)을 바탕으로 개발하였다.

아울러 화자의 전반적인 의사소통능력에 대한 인식을 알아 보기 위해 의사소통 평정 척도가 개발되었다(Logan \& O'Connor, 2012). 척도의 문항은 총 세 가지로(즉, (a) 이 사람은 부드럽고 유창하게 말한다, (b) 이 사람은 효과적으로 의사소통을 한다, (c) 이 사람은 분명하게 정보를 말한다) 구성하였고 5점 척도(1 점은 ‘전혀 그렇지 않다', 5 점은 ‘매우 그렇다')로 평가하여 3 문 항의 평균값으로 최종적인 의사소통 평정값을 산출하였다. 마 지막으로 화자의 행동적 특성(예를 들어, 비협조적-협조적, 소 심한-대담한)에 대한 전반적인 인상을 알아보기 위해 Woods $\&$ Williams(1976)를 바탕으로 의미 차이 평정 척도를 개발하였 다. 총 21 쌍의 문항으로 7점 척도(1점은 '매우 비협조적' 또는 ‘매우 소심한', 7점은 ‘매우 협조적' 또는 ‘매우 대담한')로 평가 하도록 구성하였다. 점수가 낮을수록 행동적 특성에 대한 부정 적 인상을, 반면 높을수록 긍정적 평가가 이루어지도록 하였다.

\section{4. 연구절차}

본 실험에 앞서 미리 준비한 질문지를 통해 연령, 성별, 교육 정도, 병력 등과 같은 기본 정보는 물론 말더듬 관련 정보(예를 들면, 본인의 말더듬(력) 또는 가족력 유무, 말더듬 관련 경험 유 무)를 조사하였다. 이후 실험대상자들에게 총 31 개의 직업과 관 련해 말하기 요구량 척도와 교육 수준 척도를 작성하게 하였다. 본 실험은 기본적으로 실험대상자가 말더듬 성인의 녹음된 음 성샘플을 듣고 해당 질문지에 답하도록 하였다. 녹음된 음성샘 플을 제시하기 전에 실험대상자들에게 다음의 지시 사항을 알 려주었다. "당신은 이제 녹음된 음성샘플을 듣게 될 것입니다. 음성샘플을 들으면서 제공된 기록지(비유창성 평가 기록지)에 유창성이 깨어지거나, 부드러운 말의 흐름이 아닌 것처럼 보이 는 곳에 동그라미나 빗금으로 표시해 주십시오. 이때 말하는 사 람의 음의 높낮이, 운율, 어조에 신경 쓰지 마시고 오직 (비)유창 성에만 주의를 기울여 들어 주십시오. 음성샘플은 총 3 번 듣게 되며 매번 기록지에 표시된 사항은 수정할 수 있습니다.” 이때 실험대상자의 비유창성 평가의 용이성을 위해 연구자가 막힘, 반복, 말소리 연장의 예시를 제공하였다. 이와 같이 실험대상자 들이 직접 비유창성을 평가하는 이유는 실험대상자가 지각하 는 비유창성이 연구자가 각 발화에서 설정한 비유창성(말더듬) 의 정도와 유의한 차이가 있는지 알아보기 위함이다.

이후 음성샘플을 첫 번째로 들려주고 의사소통 평정 척도를 작성하도록 하였다. 동일한 음성샘플을 두 번째로 다시 들려준 후 직업 조언 척도(또는 의미 차이 평정 척도)를, 마지막으로 다 시 음성샘플을 들려준 후 의미 차이 평정 척도(또는 직업 조언 척도)를 작성하도록 하였다. 결국, 직업 관련 말하기 요구량 척 
도와 교육 수준 척도는 음성샘플을 듣기 전, 직업 조언 척도와 의미 차이 평정 척도는 발화샘플을 최소한 두 번 이상(2 3회) 들 은 후 작성하도록 하였다. 이는 듣게 될 발화샘플과 무관하게 단순히 특정 직업(예를 들면, 변호사)과 관련해 말하기 요구량 과 교육 수준 정도를 측정하기 위하여 말하기 요구량 척도와 교 육 수준 척도는 음성샘플을 듣기 전에 그리고 (어느 정도) 타당 한 수준에서의 직업 조언 평정과 의미 차이 평정을 위해 최소 2 회 이상(2 3회) 발화샘플을 듣고 난 후 직업 조언 척도와 의미 차이 평정 척도를 작성하도록 진행하였다. 순서효과에 대한 가 능성을 고려해 직업 조언 척도와 의미 차이 평정 척도는 실험대 상자에 따라 순서를 바꾸어 제공하였다. 음성샘플은 헤드셋 (Microsoft LifeChat, LX-3000)을 착용한 후 적절한 듣기 수준(75 $\mathrm{dB}$ SPL 이내, Rami et al., 2005)에서 제시하였다. 실험 전 모든 실 험대상자는 충분한 실험 설명을 바탕으로 서면동의서를 작성 하도록 하였다. 실험 절차를 순서도(flow chart)로 표현해 보면 그림 1 과 같다.

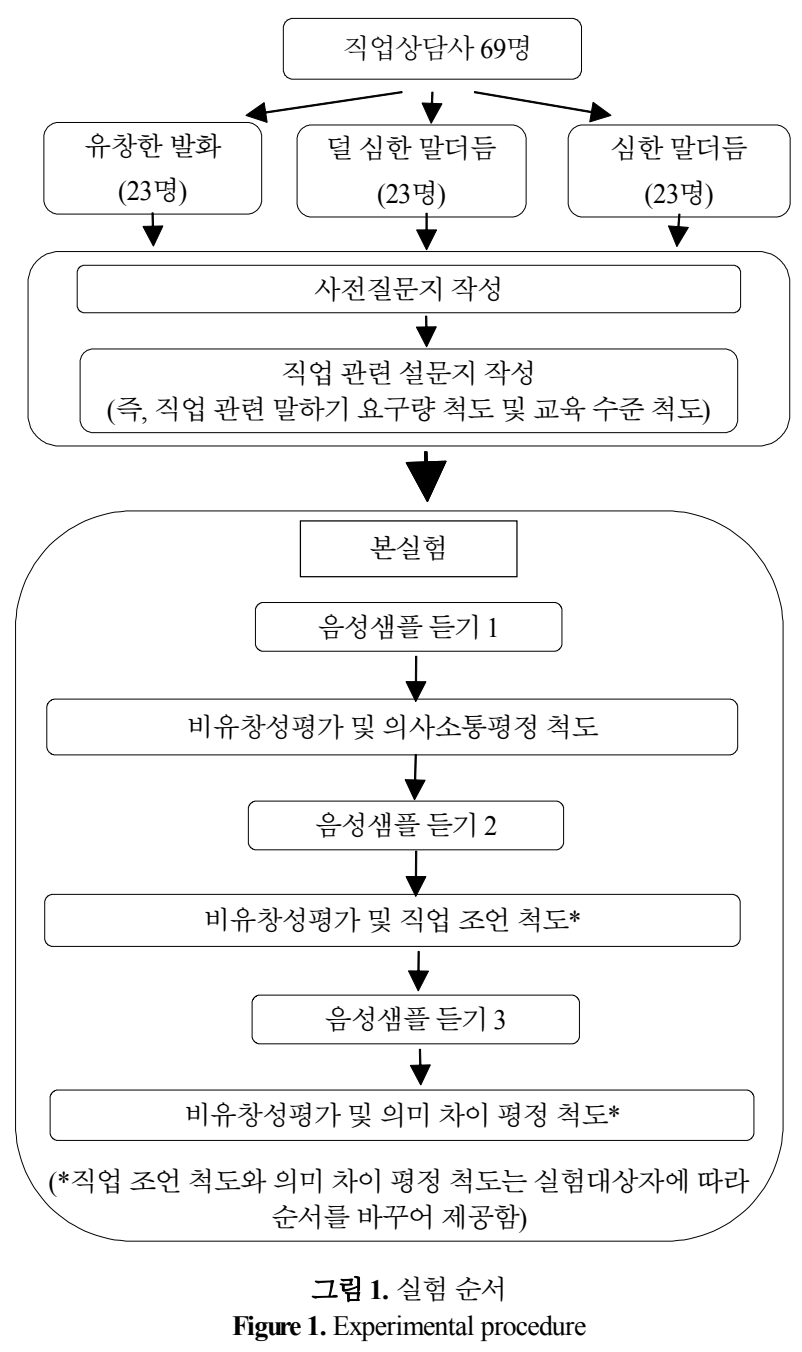

\section{5. 통계분석}

실험대상자가 답한 설문지의 답변을 바탕으로 직업 관련 말 하기 요구량 정도와 교육 수준 정도, 비유창성 빈도, 직업 추천 평정, 의사소통 평정, 의미 차이 평정에 있어 실험조건(유창한
발화, 덜 심한 말더듬, 심한 말더듬) 간에 유의미한 차이가 발생 하는지를 살펴보기 위하여 일원분산분석(one-way ANOVA) 또 는 Kruskal Willis 검정(오차 분산의 동일성 가정이 위배된 경 우), 혼합요인분산분석(mixed factor ANOVA), 다변량분산분석 (MANOVA)을 실시하였다. 직업 추천 정도와 관련 요인들(직업 관련 말하기 요구량 정도와 교육 수준 정도, 의사소통 평정, 의 미 차이 평정) 간의 상관분석은 31 개의 직업 기준에 따른 관련 변인들이 Shapiro-Wilk 검정에서 정규성을 만족하지 못하여 $(p<.05)$ Spearman 상관검정(Spearman correlation test)을 실시하였 다. 효과크기는 ANOVA와 MANOVA에서 부분에타제곱 $\left(\eta_{\mathrm{p}}{ }^{2}\right)$ 값 을, 상관분석에서 $r h o$ 값을 통해 측정하였다. 본 연구의 모든 통 계처리는 SPSS v. 22 프로그램을 이용하여 분석하였다.

\section{3. 연구결과}

3.1. 비유창성 빈도

세 가지 실험조건(유창한 버전, 덜 심한 말더듬, 심한 말더듬) 간 비유창성 빈도의 차이를 살펴보기 위하여 일원분산분석(one way ANOVA)을 실시한 결과, Levene 검정에서 오차 분산의 동 일성 가정이 위배되어 $[F(2,66)=22.321, p<.001]$ Kruskal Willis 검 정을 실시하였다. 분석 결과, 실험조건 간에 유의한 차이가 나타 났다 $\left[X^{2}(2)=48.812, p<.001\right]$. 사후검정으로 Bonferroni 교정(유의 수준=.016)을 통한 Mann Whitney U 검정을 실시하였으며 모든 실험조건 간 비교에서 유의한 차이가 나타났다 $(p<.001)$. 이를 통 해 실험대상자는 비유창성의 빈도에 있어 유창한 발화, 덜 심한 말더듬, 심한 말더듬 간 유의한 차이를 인지하고 있음을 알 수 있다. 유창한 발화와 덜 심한 말더듬에서는 비유창성의 중위수 (median)가 실제 횟수(유창한 발화는 0 회, 덜 심한 말더듬은 15 회)와 큰 차이를 보이지 않았지만 심한 말더듬에서는 실제 횟수 (78회)와 비교적 큰 차이를 보였다. 이는 기본적으로 말더듬에 대한 전문지식이 없는 실험대상자(직업상담사)가 실제 말더듬 빈도를 파악하는데 발생할 수 있는 어려움으로 인한 것으로 사 료된다. 특히 막힘의 경우, 발화 시 단순한 긴장으로 나타날 수 있기에 제공된 음성 자료만을 가지고는 분명한 인지가 어려울 수 있다. 그림 2는 비유창성 빈도에 대한 실험조건 간 차이를 보 여주고 있다. 


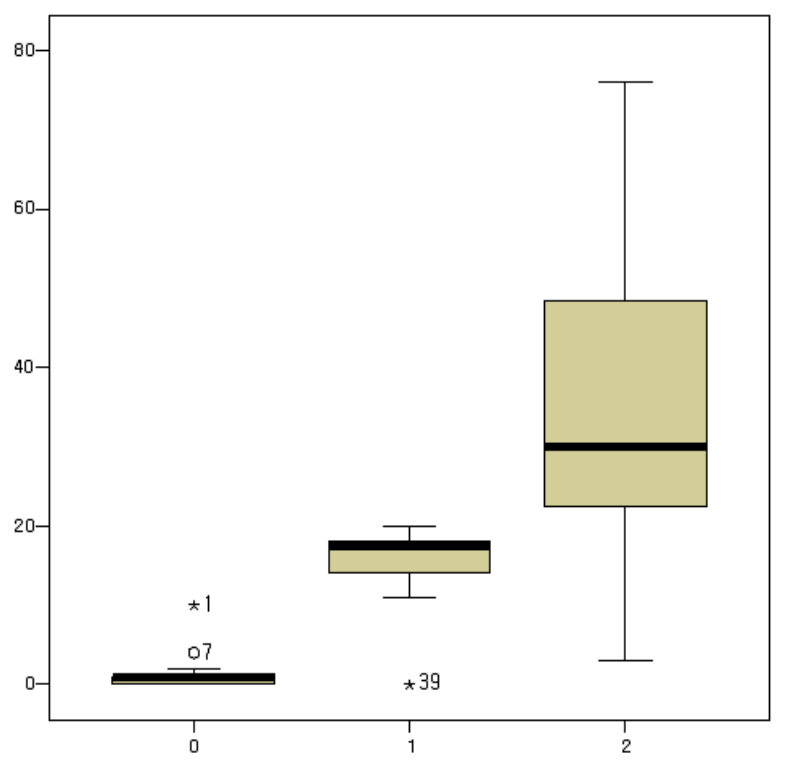

그림 2. 실험조건에 따른 비유창성 빈도 $(0=$ 유창한 발화, $1=$ 덜 심한 말더듬, $2=$ 심한 말더듬 $)$

Figure 2. Disfluency frequency across the experimental conditions (0: fluent version, 1: less-severe stuttering version, 2: severe stuttering version)

3.2. 직업 관련 교육 수준과 말하기 요구량 정도

다변량 분산분석(MANOVA) 결과, 실험조건 간 직업 관련 교 육 수준 $\left[F(62.000,74.000)=.612, p=.976, \eta_{\mathrm{p}}{ }^{2}=.339\right]$ 과 말하기 요구 량 정도에 있어 $\left[F(62.000,74.000)=.752, p=.875, \eta_{\mathrm{p}}^{2}=.387\right]$ 모두 유 의한 차이가 나타나지 않았다. 따라서 전체 실험대상자(69명)를 통합해 직업 관련 교육 수준과 말하기 요구량 정도를 기준으로 4개의 직업군(교육 수준과 말하기 요구량 정도가 모두 높은 직 업군, 교육 수준은 높지만 말하기 요구량 정도는 낮은 직업군, 교육 수준은 낮지만 말하기 요구량 정도는 높은 직업군, 교육 수준과 말하기 요구량 정도가 모두 낮은 직업군)으로 분류하였 다. 그림 3 은 4 개의 직업군을 산점도(scatter-plot)로 표시한 것으 로, $\mathrm{X}$ 축과 $\mathrm{Y}$ 축은 개별 직업의 교육 수준과 말하기 요구량 정도 의 평균을 의미하며 각 축의 참조선(reference line)은 31 개의 직 업들의 전체 평균값(교육 수준 $=3.48$, 말하기 요구량 $=3.43$ )을 보 여주는 것이다.

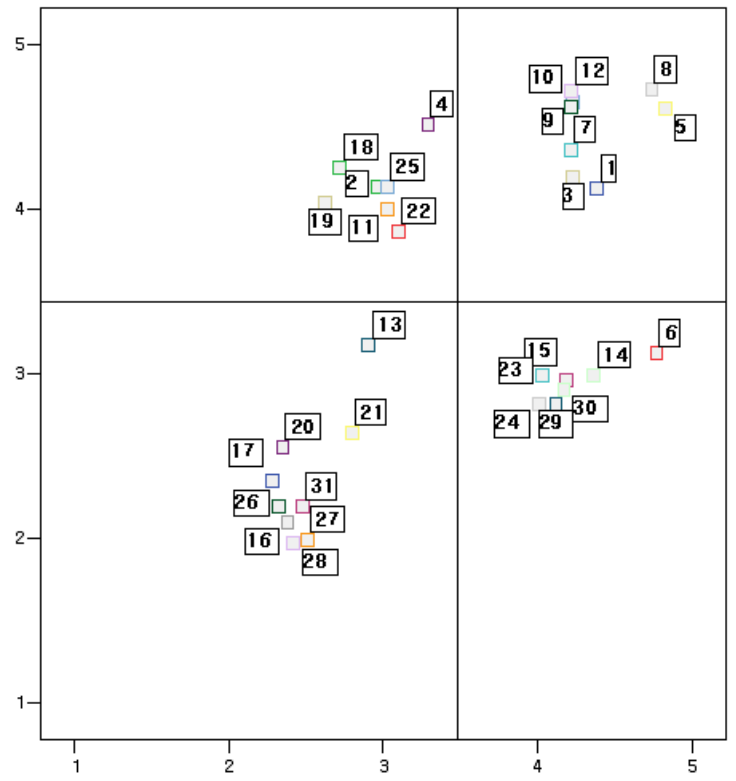

그림 3. 31 개 직업 관련 말하기 요구량 정도와 교육 수준 정도 평균 $(1=$ 기업고위임원 $(\mathrm{CEO}), 2=$ 안내 및 접수사무원, $3=$ 증권 및 외환딜러, $4=$ 보험관련영업원, $5=$ 대학교수, $6=$ 연구원, $7=$ 초등학교 교사, $8=$ 변호사, $9=$ 상담전문가, $10=$ 통역사, $11=$ 배우,

$12=$ 아나운서, $13=$ 연예인매니저, $14=$ 항공기조종사, $15=$ 항해사, 16 = 화물차운전원, 17 = 택배원, $18=$ 텔레마케터, $19=$ 홍보도우미, 20 = 경비원, 21 = 애완동물미용사, 22 = 스포츠 및 레크레이션 강사,

23 = 건축가, 24 = 측량전문가, 25 = 결혼상담원, 26 = 도배공, $27=$ 자동차부품 조립원, $28=$ 용접원, $29=$ 네트워크시스템개발자, $30=$ 소프트웨어개발자, $31=$ 어업 관련종사자 $)(x$ 축 $=$ 교육 수준 정도, $\mathrm{y}$ 축 $=$ 말하기 요구량 정도)

Figure 3. Mean ratings of speaking demands and educational requirements associated with the 31 occupations

$(1=\mathrm{CEO}, 2=$ receptionist (or usher), $3=$ stock or foreign exchange dealer, $4=$ insurance clerk or manager, $5=$ college professor, $6=$ engineer,

$7=$ elementary-school teacher, $8=$ lawyer, $9=$ counselor, $10=$ interpreter, $11=$ actor, $12=$ announcer, $13=$ entertainment manager, $14=$ airplane pilot, $15=$ mate, $16=$ truck driver, $17=$ mail carrier, $18=$ telemarketing salesman, $19=$ public relations assistant, $20=$ janitor, $21=$ pet hair designer, $22=$ sports or recreational instructor, $23=$ architect, $24=$ land surveyor, $25=$ matchmaker or wedding planer, 26 = wall paper specialist, $27=$ car mechanic, $28=$ welding specialist, $29=$ network system engineer, $30=$ software engineer, $31=$ fishery worker) $(\mathrm{x}$-axis: educational requirements, y-axis: speaking demands)

\section{3. 직업 추천 정도}

직업 관련 교육 수준과 말하기 요구량을 바탕으로 한 4개의 직업군에 따른 직업 추천 정도와 양상을 알아보기 위해 4 개의 직업군을 개체내요인으로, 3 개의 실험조건을 개체간요인으로 혼합요인분산분석을 실시하였다. 분석결과, 직업군과 실험조 건 간 상호작용 $\left[F(4.035,133.162)=20.969, p<.001, \eta_{\mathrm{p}}{ }^{2}=.389\right]$, 직업 군 간 $\left[F(2.018,133.162)=148.002, p<.001, \eta_{p}^{2}=.692\right]$ 그리고 실험조 건 간 $\left[F(2,66)=6.642, p=.002, \eta_{\mathrm{p}}{ }^{2}=.168\right]$ 에서 모두 유의한 차이가 나타났다. 그림 4에서 나타난 것처럼 덜 심한 말더듬과 심한 말 더듬에서 (직업 관련 교육 수준 정도에 상관없이) 말하기 요구 량이 높은 직업군(직업군 1,2 )에서 전반적으로 낮은 직업 추천 정도를 보이는 반면, 말하기 요구량이 낮은 직업군(직업군 3,4 ) 
에서는 높은 추천 정도를 보이고 있다. 반면, 유창한 발화에서는 모든 직업군에서 비교적 유사한 수준에서의 직업 추천 양상을 보이고 있다.

사후검정으로 일변량 분산분석 결과, 직업군 1 (말하기 요구 량은 높지만 교육 수준은 낮은 직업)에서 실험조건 간 차이가 나타났다 $[F(2,66)=25.425, p<.001]$. 사후 검정 결과, 유창한 발화 와 덜 심한 말더듬 간 $(p<.001)$, 유창한 발화와 심한 말더듬 간 $(p<.001)$ 에서 유의한 차이가 나타났다. 반면, 덜 심한 말더듬과 심한 말더듬 간에서는 유의한 차이가 나타나지 않았다 $(p=1.000)$. 직업군 2(말하기 요구량과 교육 수준이 모두 높은 직업)에서도 실험조건 간 유의한 차이가 나타났다 $[F(2,66)=25.319, p<.001]$. 사후 검정 결과, 유창한 발화와 덜 심한 말더듬 간 $(p<.001)$, 유창 한 발화와 심한 말더듬 간 $(p<.001)$ 에서 유의한 차이가 나타난 반 면, 덜 심한 말더듬과 심한 말더듬 간에는 유의한 차이가 나타나 지 않았다 $(p=.193)$. 직업군 3(말하기 요구량과 교육 수준이 모두 낮은 직업)에서도 실험조건 간 유의한 차이가 나타났다 $[F(2$, 66) $=12.715, p<.001]$. 사후 검정 결과, 유창한 발화와 덜 심한 말 더듬 간 $(p<.001)$, 유창한 발화와 심한 말더듬 간 $(p=.002)$ 에서 모 두 유의한 차이가 나타난 반면, 덜 심한 말더듬과 심한 말더듬 간에는 유의한 차이가 나타나지 않았다 $(p=.628)$. 마지막으로 직 업군 4(말하기 요구량은 낮고 교육 수준이 높은 직업)에서는 실 험조건 간 유의한 차이가 나타나지 않았다 $[F(2,66)=.208, p=.483]$. 결국 말더듬인 경우, 심한 정도에 상관없이 말하기 요구량 정도 가 높은 직업군에 대해 상대적으로 낮은 추천 정도를 보인 반면, 말하기 요구량 정도와 교육 수준이 낮은 직업군은 높게 추천하 는 결과가 나타났다.

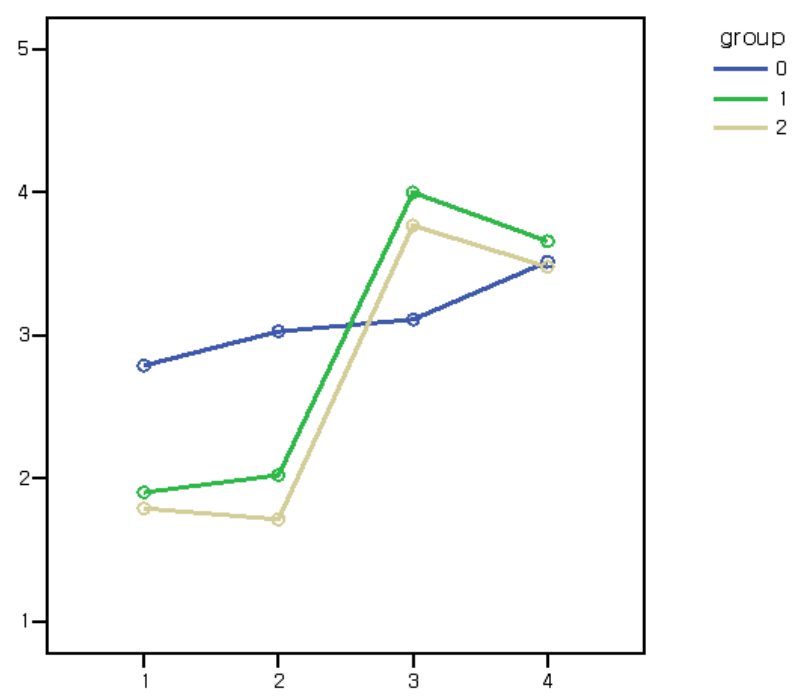

그림 4. 실험조건에 따른 평균 직업 추천 정도

(group 0, 유창한 발화; group 1, 덜 심한 말더듬; group 2, 심한 말더듬; 1 , 직업 관련 말하기 요구량은 높지만 교육 수준 정도는 낮은 직업군; 2 , 직업 관련 말하기 요구량과 교육 수준 정도가 모두 높은 직업군; 3 , 직업 관련 말하기 요구량과 교육 수준이 모두 낮은 직업군; 4 , 직업 관련 말하기 요구량은 낮은 반면 교육 수준 정도는 높은 직업군)

Figure 4. Mean suitability ratings for occupations in the four demand quadrants(group 0, fluent version; group 1, less-severe stuttering version; group 2, severe stuttering version; 1, H Spk+L Educ; 2, H Spk +H Educ;

3, L Spk+L Educ; 4, L Spk+H Educ as labeled on the x-axis)

3.4. 직업 관련 변수와 직업 추천 정도 간 상관성

먼저 직업 관련 말하기 요구량 정도에 대한 인식과 직업 추천 정도(4개 직업군 추천 전체 평균) 간의 상관관계를 분석한 결과, 전체적으로 유의한 수준에서 부적 상관관계를 나타냈다 $r h o=$ $-.909, p<.001)$. 더 나아가 각 실험조건에서의 상관관계를 분석 한 결과, 유창한 발화에서는 유의한 상관관계가 나타나지 않은 반면 $(r h o=-.318, p=.081)$, 덜 심한 말더듬 $(r h o=-.912, p<.001)$ 과 심 한 말더듬에서 $(r h o=-.959, p<.001)$ 모두 유의한 수준에서 부적 상관관계가 나타났다. 직업 관련 교육 수준 정도에 대한 인식과 직업 추천 간의 상관관계를 분석한 결과, 전체적으로 부적 상관 관계를 나타났다 $(r h o=-.398, p=.027)$. 각 실험조건에서의 상관관 계를 분석한 결과, 유창한 발화 $(r h o=.244, p=.185)$ 에서는 유의한 상관관계를 보이지 않았으며, 덜 심한 말더듬 $(r h o=-.465, p=.008)$ 과 심한 말더듬 $(r h o=-.427, p=.017)$ 에서 모두 유의한 수준에서 상관관계를 보였다. 이는 직업 추천에 있어 유창한 발화보다 두 말더듬에서 말하기 요구량 정도와 교육 수준 정도가 전반적으 로 유의한 수준에서의 부적 상관관계를, 특히 말하기 요구량 정 도가 교육 수준 정도보다 더 높은 부적 상관성을 보여주고 있다. 이는 말더듬의 경우, 직업 관련 말하기 요구량 정도에 대한 인 식이 말더듬 성인의 직업 추천에 있어 매우 유의한 요인임을 보 여주는 결과라 할 수 있다. 결국 말더듬인 경우, 말하기 요구량 이 낮은 직업을 더 높게 추천하는 이전 결과와(3.3. 직업 추천 정 도에서 논의) 동일한 맥락으로 해석될 수 있을 것이다. 


\section{5. 의사소통 평정}

일변량 분산분석 결과, 실험조건 간 유의한 차이가 나타났다 $[F(2,66)=22.989, p<.001]$. 사후검정 결과, 유창한 발화와 덜 심한 말더듬 간 $(p<.001)$, 유창한 발화와 심한 말더듬 간에는 $(p<.001)$ 유의한 차이가 나타난 반면, 덜 심한 말더듬과 심한 말더듬 간에 서는 $(p=.293)$ 유의한 차이가 나타나지 않았다. 그림 5 에서 의사 소통 평정에 대한 실험조건 간 차이를 보여주고 있다.

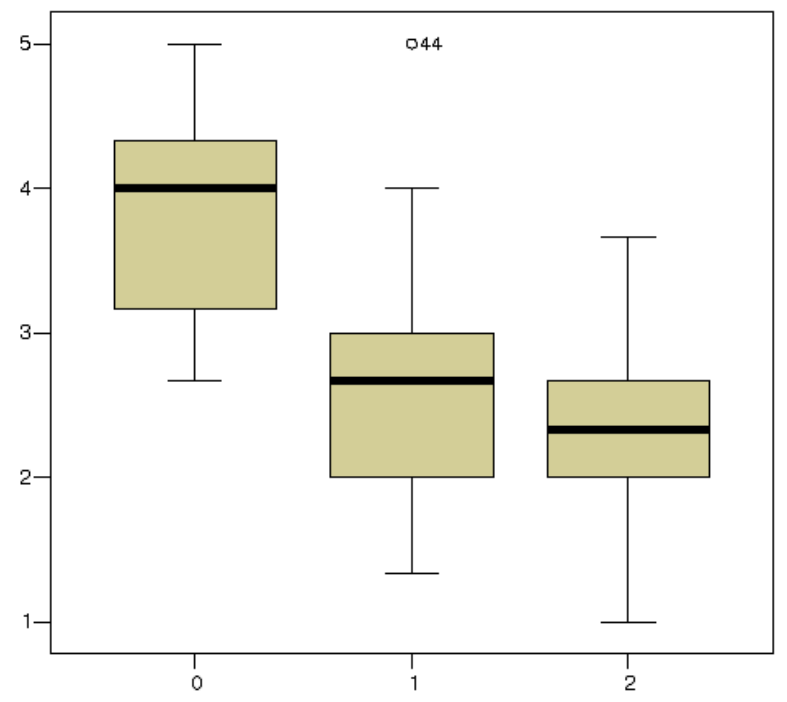

그림 5. 실험조건에 따른 의사소통 평정 $(0=$ 유창한 발화, $1=$ 덜 심한 말더듬, $2=$ 심한 말더듬 $)$

Figure 5. Communicative (performance) ratings across the experimental conditions (0: fluent version, 1: less-severe stuttering version, 2: severe stuttering version)

\section{6. 의사소통 평정과 직업 추천 정도 간 상관성}

의사소통 평정평균과 전체 직업 추천 정도(4개 직업군 추천 전체 평균) 간에 유의한 수준에서의 정적 상관관계 $(r h o=.553$, $p<.001)$ 가 나타났다. 더 나아가 4 개의 각 직업군에서 직업 추천 정도와의 상관관계를 분석한 결과, 의사소통 평정은 교육 정도 에 상관없이 말하기 요구량이 높은 직업군과 높은 정적 상관관 계를 보인 반면, 말하기 요구량과 교육수준이 모두 낮을 직업군 과는 부적 상관관계를 보였다 $(r h o=-.248, p<.05)$. 이는 의사소통 평정이 높을수록 말하기 요구량이 높은 직업을 더 추천하고 말 하기 요구량과 교육수준이 모두 낮은 직업은 덜 추천한다는 의 미로 해석될 수 있다. 표 3 은 의사소통 평정과 4 개의 직업군에서 의 추천 정도와의 상관관계 분석 결과를 보여주고 있다.

표 3. 직업군에 따른 의사소통 평정과 직업추천 간의 상관관계

Table 3. Correlations between communication rating scales and the occupational advice ratings for the four quadrants

\begin{tabular}{|c|c|c|c|c|c|}
\hline & & $\begin{array}{c}\text { 말하기 상 } \\
\text { 교육 하 }\end{array}$ & \begin{tabular}{|c|} 
말하기 상 \\
교육 상
\end{tabular} & \begin{tabular}{|c|} 
말하기 하 \\
교육 하
\end{tabular} & $\begin{array}{c}\text { 말하기 하 } \\
\text { 교육 상 }\end{array}$ \\
\hline \multirow{2}{*}{$\begin{array}{l}\text { 의사소통 } \\
\text { 평정 }\end{array}$} & rho & .704 & .721 & -.248 & .145 \\
\hline & $p$ & $<.001^{* *}$ & $<.001^{* *}$ & $.04^{*}$ & .236 \\
\hline
\end{tabular}

\section{7. 의미 차이 평정}

의미 차이 평정에서 실험조건 간의 차이를 알아보기 위해 다변량 분산분석을 실시하였다. 분석 결과, 실험조건 간 의미 차이 평정에 있어서 유의한 차이가 나타나지 않았다 $[F(42.000$, 94.000)=1.186, $p=.245]$. 이는 유창함의 정도(말더듬의 유무)에 따라 (발화를 통해 엿볼 수 있는) 행동적 특성(예를 들어, 비협조 적-협조적, 소심한-대담한)에 대한 인상에 있어서는 유의한 차이가 나타나지 않음을 보여주는 결 과이다.

3.8. 의미 차이 평정과 직업 추천 정도 간 상관성

의미 차이 평정평균과 전체 직업 추천 정도(4개 직업군 추천 전체 평균) 간에 유의한 수준에서의 정적 상관관계가 나타났다 $(r h o=.271, p=.024)$. 더 나아가 4 개의 각 직업군에서 직업 추천 정 도와의 상관관계를 분석한 결과, 말하기 요구량과 교육 수준이 모두 높은 직업군을 제외한 다른 직업군에서 모두 유의한 상관 관계가 나타나지 않았다. 이는 말하기 요구량과 교육 수준이 높 은 직업군에서는 대상자의 행동적 인상에 대한 평정이 직업 추 천 정도와 유의한 상관성을 보인 반면, 다른 직업군에서는 유의 한 상관성이 없음을 보여주는 결과이다. 이는 행동적 특성이 긍 정적일수록 말하기 요구량과 교육 수준 정도가 높은 직업군을 더 추천하는 의미로 해석될 수 있다. 표 4에서 의미 차이 평정과 4 개의 직업군에서의 추천 정도와의 상관관계 분석 결과를 보여 주고 있다.

표 4. 직업군에 따른 의미 차이 평정과 직업추천 간의 상관관계

Table 4. Correlations between semantic differential scales and the occupational advice ratings for the four quadrants

\begin{tabular}{l|c|c|c|c|c}
\hline \multicolumn{2}{c|}{} & $\begin{array}{c}\text { 말하기 상_- } \\
\text { 교육 하 }\end{array}$ & $\begin{array}{c}\text { 말기 상_- 말하기 하_육 상 } \\
\text { 교육 하 }\end{array}$ & $\begin{array}{c}\text { 말하기 하- } \\
\text { 교육 상 }\end{array}$ \\
\hline $\begin{array}{c}\text { 의미 차이 } \\
\text { 평정 }\end{array}$ & $r h o$ & .183 & .271 & -.035 & .227 \\
\cline { 2 - 6 } & $p$ & .133 & $.024^{*}$ & .777 & .061 \\
${ }^{*} p<.05$.
\end{tabular}

\section{4. 논의 및 결론}

본 연구의 결과를 요약해 보면, 첫째, 발화의 유창성 정도 또 는 말더듬의 유무에 따라 직업상담사의 직업 추천 양상이 달라 졌다. 구체적으로, 두 말더듬 상황(덜 심한 말더듬과 심한 말더 듬)에서 교육 수준에 상관없이 말하기 요구량이 높은 직업군(예 를 들어, 대학교수, 변호사, 홍보도우미)은 낮은 추천 정도를 보 인 반면, 말하기 요구량과 교육 수준 정도가 모두 낮은 직업군 (예를 들어, 용접공, 항해사, 택배원)에서는 높은 추천 정도를 보 였다. 둘째, 말더듬 상황에서 직업 추천 정도에 있어 직업 관련 말하기 요구량과 교육 수준 정도가 모두 유의한 수준에서 부적 상관관계를 보였으며, 특히 말하기 요구량 정도가 교육 수준 정 도보다 더 높은 부적 상관관계를 보여주었다. 반면, 유창한 발화 에서는 모두 유의한 수준에서의 상관관계가 나타나지 않았다. 셋째, 의사소통 평정에 있어 실험조건 간 유의한 차이가 나타났 으며 특히, 두 말더듬과 유창한 발화 간 유의한 차이가 나타났지 
만, 두 말더듬 간에는 유의한 차이가 나타나지 않았다. 의사소통 평정과 직업 추천 정도 간에는 교육 정도에 상관없이 말하기 요 구량이 높은 직업군에서 유의한 수준에서 정적 상관관계가 나 타났다. 이는 의사소통평정이 높을수록 말하기 요구량이 높은 직업군을 더 추천한다는 의미로 해석될 수 있다. 마지막으로, 행 동적 특성에 대한 의미 차이 평정에 있어 실험조건 간 차이는 나타나지 않았다. 또한 의미 차이 평정과 직업 추천 정도 간에 는 유의한 상관관계가 나타났는데 특히, 말하기 요구량과 교육 수준이 모두 높은 직업군(예를 들어, 대학교수, 변호사, 상담전 문가)에서 유의한 수준에서의 정적 상관관계가 나타났다. 이는 행동적 특성이 긍정적일수록 말하기 요구량과 교육 수준이 높 은 직업군을 추천한다는 의미로 해석될 수 있다.

위의 결과를 통해 몇 가지 논의를 해본다면, 첫째, 발화의 유 창성 정도 또는 말더듬의 유무에 따라 직업상담사의 직업 추천 양상이 달라졌다는 것이다. 위에서 언급한 것처럼, 두 말더듬 상 황에서 직업 관련 말하기 요구량이 높은 직업군은 낮게, 직업 관련 말하기 요구량과 교육 수준 정도가 낮은 직업군은 높게 추 천되었다. 이러한 결과는 직업 추천 정도와 직업 관련 말하기 요 구량 정도 인식 간에 나타난 높은 부적 상관관계(덜 심한 말더 듬에서는 $r h o=-.912, p>.001$, 심한 말더듬에서 $r h o=-.959, p>.001)$ 에서도 동일하게 엿볼 수 있다. 이렇게 말더듬 성인에 대한 (직 업상담사의) 직업 추천이 말하기 요구량이 상대적으로 낮은 직 업군에 한정되고 있음은 이전 연구(Gabel et al., 2004; Logan \& O'Connor, 2012)와 동일한 결과로 직업 추천의 제한성은 사회적, 문화적 차이를 넘어 말더듬 성인이라면 누구나 경험할 수 있는 일종의 ‘보편적 문제’라는 점을 시사하고 있다. 또한 말더듬 성 인의 직업 추천에 있어 일반인(Logan \& O'Connor, 2012)과 관련 전문가라 할 수 있는 직업상담사 간에도 유의한 차이가 없음을 보여주는 결과이기도 하다.

둘째, 본 연구는 말더듬 성인의 음성샘플만을 바탕으로 직업 상담사의 직업 추천 양상과 정도를 알아보았다. 이는 기본적으 로 말더듬 성인의 발화 유창성에 따른 직업 추천의 차이를 알아 보고자 하는 본 연구의 주목적에 따른 것이라 할 수 있다. 연구 방법에서 서술하였듯이, 발화 유창성을 제외한 다른 변수들, 특 히, 화자의 외모, 얼굴 표정, 몸동작 등을 통해 드러나는 시각적 인상에 의한 평정 가능성을 배제하기 위한 목적으로 본 연구에 서는 음성샘플만을 사용하였다. 결국, 음성샘플만 들려주었을 때 직업상담사의 직업 추천은 직업 관련 말하기 요구량 정도나 의사소통능력과 같은 요인들이 좀 더 유의한 영향을 끼치면서 상대적으로 이러한 요인들이 덜 중요하게 여겨지는 직업군들 (예를 들어, 용접공, 항해사, 택배원)에 대해 높은 추천 결과가 나타났다. 하지만 말더듬은 이러한 구어 비유창성뿐 아니라 탈 출행동과 회피행동과 같은 여러 부수행동 등을 포함하는 복합 적인 형태로 나타나기에 음성파일만으로는 실제 말더듬 성인 을 대표하기에는 무리가 있을 것이다. 이러한 점을 보완해 향후 음성샘플이 아닌 여러 부수행동 등을 시각적으로 보여주는 동 영상샘플을 이용해 직업 추천 양상이 어떻게 달라지는지에 대 한 후속연구가 필요하다.
셋째, 실제 채용현장에서 발화 유창성 정도나 의사소통능력 만 중요하게 고려된다면 이러한 능력에 있어 상당한 제한성을 가지고 있는 말더듬 성인은 실제 직무 관련 역량이나 능력을 제 대로 평가받지 못할 가능성이 높다. 요즘 대면 평가의 중요성이 강조되는 것이 사실이지만 직무 형태에 따라 실제 채용현장에 서는 단순히 말의 문제 또는 능력만을 고려해 대상자를 평가하 지는 않는다. 실제 직무와 연관되어 있는 다양한 상황에서의 대 처능력을 본다든지, 각종 심리검사를 활용해 구직자의 인성을 파악한다든지, 직무와 관련된 경험 유무 또는 경력 기간과 같은 매우 다양한 측면에서 평가가 이루어진다. 또한 담당하는 업무 의 성격에 따라 중요시되는 역량이나 채용기준이 다를 수 있기 에 단순히 '말의 능력'만을 고려해 직업 추천이 이루어질 수는 없다. 이런 맥락에서 직업상담사의 실제 직업 추천(상담)은 구 직자의 연령, 성별, 학력, 직무 관련 이력 및 경험, 자격증, 인성, 희망 직종의 특성 등 모든 관련 사항들이 충분히 고려되는 매우 복합적이며 역동적인 과정이라 할 수 있다. 본 연구의 실험대상 자(직업상담사)들이 제공한 말더듬 성인을 위한 몇 가지 조언 (또는 의견)들도 이러한 논의와 맥락이 닿아 있다. 예를 들어, “일단 자신의 말의 문제에 얽매이지 말고 자신이 좋아하는 분 야, 또는 잘하는 일을 찾고 개발하세요", “희망 직종의 특성을 잘 파악해 구체적인 직무와 관련된 경험과 이력을 충분히 쌓으 세요” 등이 이에 포함되는 조언들이다. 결국 말을 더듬는 사람 이 자신의 장점을 최대한으로 개발해 이러한 장점들이 효과적 으로 활용될 수 있는 직종을 선택, 준비하는 것이 무엇보다 중요 하다 할 것이다.

넷째, 의미 차이 평정에 있어 실험조건 간에 유의한 차이가 나타나지 않은 결과는 발화의 유창성 정도 또는 말더듬의 유무 를 통해 엿볼 수 있는 행동적 특성에 대한 인상(예를 들어, 비협 조적, 대담한)에 유의하게 영향을 미치고 있지 않음을 보여주는 것이다. 또한 직업 추천 정도와 의미 차이 평정 간의 상대적으 로 낮은 상관관계 $(r h o=.271, p=.024)$ 는 직업 추천에 있어 발화를 통해 드러나는 개인의 행동적 특성에 대한 간접적 평정보다 발 화를 통해 직접 드러나는 유창성 정도나 의사소통 평정이 추천 양상이나 정도를 결정하는 중요한 요인임을 보여주는 것이다. 하지만 음성샘플만으로 개인의 행동적 특성에 대한 인상을 평 정하기에는 한계가 있을 수 있기에 향후 말 유창성 뿐 아니라 개인의 행동적 특성도 좀 더 면밀하게 관찰할 수 있는 자극상황 (예를 들어, 말더듬 성인의 발화 동영상)을 제시하거나, 행동적 특성이 통제된 상황에서(예를 들어, 소심한 또는 대담한) 직업 추천 정도와의 상관정도를 알아보는 연구도 진행해 볼 필요가 있을 것이다.

마지막으로 임상적 함의와 관련해, 먼저 본 연구결과가 말더 듬 성인들의 직업 상담과 관련해 하나의 유용한 가이드라인으 로 사용될 수 있을 것이다. 하지만 본 연구 결과를 그대로 적용 해 (일관적으로) 말더듬 성인들에게는 직업 관련 말하기 요구량 정도가 낮은 직업들만을 추천한다면 이는 이들에 대한 일반적 고정관념이나 선입견을 그대로 수용한다는 의미로 해석될 수 있기에 실제 사용에는 어느 정도 주의가 요구된다고 할 수 있다. 
또한 이들을 위해 좀 더 실제적이면서도 효율적인 치료방안을 계획, 실행해 볼 필요가 있다. 예를 들어, 면접상황이나 직장에 서의 몇 가지 ‘대표상황'(예를 들어, 면접관이 말더듬에 대해 질 문하는 상황, 직장 내 전화상황, 직장 내 프리젠테이션(발표) 상황 등)의 목록을 만들어 각 상황에서의 개별화된 유창성 훈 련을 시도해보는 것이다. 이때 단순히 말더듬의 완전한 소거 (elimination)에 목적을 두지 말고 좀 더 현실적이고 효율적인 의 사소통능력 향상에 비중을 두면서 개별치료를 진행하는 것이 다. 동시에 말더듬으로 인한 공포 또는 두려움으로 인해 발생하 는 심리적 문제나 의사소통에 대한 부정적 태도, 이로 인해 발생 할 수 있는 회피행동에 대한 중재도 함께 이루어져야 할 것이다. 결국 말더듬만을 따로 떼어서 치료하는 것이 아닌 말더듬는 사 람의 ‘전체'를 치료하는 데 모든 노력을 기울여야 할 것이다. 이 를 통해 말더듬 성인이 사회의 건전한 구성원으로서 자신에게 맡겨진 사회적 역할이나 책임을 성공적으로 수행할 수 있도록 효율적으로 도와야 할 것이다.

본 연구의 제한점과 향후 연구방향에 대해 논해본다면, 첫째, 본 연구는 가상의 화자가 아닌 실제 말더듬 성인의 음성샘플을 바탕으로 실험을 진행하였다. 음성샘플을 통해 좀 더 실제적인 말더듬(인)에 대한 평가가 가능하겠지만 의사소통능력이나 유 창성 정도 이외의 다른 변수(예를 들어, 행동적 특성에 대한 인 상)에 대한 평가는 간접적이거나 상대적으로 제한적일 수밖에 없다. 따라서 향후 이러한 부분을 보완해 행동적 특성에 대한 인 상 정도를 엿볼 수 있는 동영상 자극을 제공하거나 행동적 특성 이 통제된 상황에서(예를 들어, 소심한 또는 대담한) 유창성 정 도 또는 말더듬 유무에 따라 직업 추천 양상이 어떻게 달라지는 지에 대한 연구를 수행해 볼 필요가 있을 것이다. 둘째, 본 연구 에 사용된 발화샘플은 30 대의 남자 말더듬 성인을 통해 생성되 었다. 향후 여자 말더듬 성인이나 다른 연령층의 발화샘플을 이 용해 말더듬 성인의 성별이나 연령의 차이에 따른 직업 추천 양 상 및 관련 요인들에 대한 연구를 진행해볼 필요도 있을 것이다. 이를 통해 결국 성별이나 연령에 따른 직업 추천 양상이나 관련 요인들의 상관성 정도가 어떻게 달라지는지 규명해볼 수 있을 것이다. 셋째, 본 연구의 실험대상자는 대부분 여성 직업상담사 이며, 주 연령대는 40 대였다. 상담 관련 업무 분야에 여성 종사 자들이 비교적 많다는 점을 주지하더라도 상대적으로 본 연구 에 참여한 남성 비율이 매우 적은(총 4명) 한계를 가지고 있다. 향후 연구에서는 국내 직업상담사의 인구통계학적 특성에 따 른 연령과 성비를 고려해 실험대상자의 수를 적절히 조정해 연 구를 진행할 필요가 있을 것이다. 이를 통해 좀 더 대표성을 가 지고 있는 실험대상자를 통한 연구가 진행될 수 있을 것이다. 마지막으로 국내 말더듬 성인을 대상으로 이들이 실제로 취업 현장에서 격게 되는 어려움이나 불평등, 의사소통장애인으로 서 효과적인 취업 준비 방안, 실제 취업한 업종의 종류와 비율, 직장생활에서 말더듬으로 겪게 되는 차별의 형태와 대처방안 등을 포함한 취업과 직장생활 전반에 대한 좀 더 포괄적이고 실 제적인 현황 관련 연구도 필요하리라 본다.

\section{References}

Bloodstein, O., \& Bernstein Ratner, N. (2008). A handbook on stuttering (6th ed.). Clifton Park, NY: Thomson Delmar Learning.

Gabel, R. M., Blood, G. W., Tellis, G. M., \& Althouse, M. T. (2004). Measuring role entrapment of people who stutter. Journal of Fluency Disorders, 29(1), 27-49.

Hurst, M. A., \& Cooper, E. B. (1983a). Vocational rehabilitation counselors' attitudes toward stuttering. Journal of Fluency Disorders, 8(1), 13-27.

Hurst, M. I., \& Cooper, E. B. (1983b). Employer attitudes toward stuttering. Journal of Fluency Disorders, 8(1), 1-12.

Ingham, R. J., Warner, A., Byrd, A., \& Cotton, J. (2006). Speech effort measurement and stuttering: Investigating the chorus reading effect. Journal of Speech, Language, and Hearing Research, 49(3), 660-70.

Jeon, H. S., \& Jeon, H. E. (2015). Characteristics of disfluency clusters in adults who stutter. Journal of Speech-Language and Hearing Disorders, 24(1), 135-144.

Kim, H. H. (1996). Perceptual, acoustical, and physiological tools in ataxic dysarthria management: A case report. Proceedings of the 2nd Conference in The Korean Society of Phonetic Sciences and Speech Technology (pp. 68-71).

Klein, J. F., \& Hood, S. B. (2004). The impact of stuttering on employment opportunities and job performance. Journal of Fluency Disorders, 29(4), 255-273.

Korea Employment Information Service. (2015). Occupational outlook handbook. Retrieved from https://www.keis.or.kr/user/extra/main /2108/publication/publicationOnlyList/jsp/LayOutPage.do? categoryIdx $=125 \&$ pubIdx $=5191 \&$ column $=\&$ search $=\&$ spage $=2 \#$ totalList

Lee, S. W. (2005). Fluency disorders. Seoul: Sigma Press.

Logan, K. J., \& O'Connor, E. M. (2012). Factors affecting occupational advice for speakers who do and do not stutter. Journal of Fluency Disorders, 37(1), 25-41.

Park, J., Oh, S., Jun, J. P., \& Kang, J. S. (2015). Effects of background noises on speech-related variables of adults who stutter. Phonetics and Speech Sciences, 7(1), 27-37.

Rami, M. K., Kalinowski, J., Rastatter, M. P., Holbert, D., \& Allen, M. (2005). Choral reading with filtered speech: Effect on stuttering. Perceptual and Motor Skills, 100(2), 421-431.

Riley, G. (1994). The stuttering severity instrument for adults and children (SSI-3) (3rd ed.). Austin, TX: PRO-ED.

Shim, H. S. (2000). A study on stereotypes of the Korean male adults who stutter. Korean Journal of Communication Disorders, 5(1), $1-17$.

Shim, H. S., Shin, M. J., \& Lee, E. J. (2010). Paradise Fluency Assessment II (P-FA-II). Seoul: Paradise Welfare Foundation.

Van Riper, C. (1982). The nature of stuttering (2nd ed). Englewood 
Cliffs, NJ: Prentice-Hall.

Wingate, M. E. (1964). A standard definition of stuttering. A Journal of Speech and Hearing Disorders, 29(4), 484-489.

Woods, C. L., \& Williams, D. E. (1976). Traits attributed to stuttering and normally fluent males. Journal of Speech and Hearing Research, 19(2), 267-278.

Yoo, K. S. (2017). Job competency development policy in the era of the 4th industrial revolution. Journal of Practical Engineering Education, $9(2), 167-174$.

- 박진 (Jin Park) 교신저자 가톨릭관동대학교 휴먼서비스대학 언어재활상담학과 조교수 강원도 강릉시 범일로 57번길 24(내곡동)

Tel: 033-649-7737

Email: gatorade70@cku.ac.kr

관심분야: 유창성장애, 음성학

- 장혜경 (Hyekyung Jang)

충남대학교 대학원 언어병리학과 박사수료

대전광역시 유성구 대학로 99

Tel: 042-821-7056

Email: boss4111@nate.com

관심분야: 신경언어장애

- 신형탁 (Hyungtak Shin)

연세대학교 대학원 언어병리학협동과정 석사과정

서울시 서대문구 연세로 50-1

Tel: 02-2228-3903

Email: hyungtak1204@yonsei.ac.kr

관심분야: 신경언어말장애, 음성장애

\section{- 조남빈 (Nambin Cho)}

연세대학교 대학원 언어병리학협동과정 석사과정

서울시 서대문구 연세로 50-1

Tel: 02-2228-3903

Email: bins94@yonsei.ac.kr

관심분야: 신경언어말장애, 삼킴장애

\section{- 박희영 (Heeyoung Park)}

이화여자대학교 대학원 언어병리학과 박사후과정연구원

서울시 서대문구 대현동 이화여대길 52

Tel: 02-3277-2120

Email: hypark1020@gmail.com

관심분야: 언어발달장애, 학습장애 


\title{
직업상담사의 말더듬 성인에 대한 직업 추천 양상과 관련 요인 분석*
}

\author{
박 진 ${ }^{1}$ 장 혜 경 $\cdot$ 신 형 탁 $\cdot$ 조 남 $^{3}{ }^{3} \cdot$ 박 희 영 ${ }^{4}$
}

${ }^{1}$ 가톨릭관동대학교 언어재활상담학과, ${ }^{2}$ 충남대학교 대학원 언어병리학과, ${ }^{3}$ 연세대학교 대학원 언어병리학협동과정, ${ }^{4}$ 이화여자대학교 대학원 언어병리학과

\begin{abstract}
국문초록
본 연구에서는 직업상담사를 대상으로 한국고용노동부에 수록된 31개의 직업군들을 바탕으로 말더듬 성인을 위 한 직업 추천 양상에 대한 실증적 연구를 진행하였다. 총 69 명의 직업상담사(실험조건 당 23 명)로 하여금 말더듬 성 인을 통해 생성된 세 가지 발화샘플(유창한 발화, 덜 심한 말더듬, 심한 말더듬) 중 하나를 듣고 제공된 척도질문지 (직업 관련 말하기 요구량 척도, 직업 관련 교육 수준 척도, 직업 조언 척도, 의사소통 평정 척도, 의미 차이 평정 척 도)를 통해 평가하였다. 실험 결과, 두 말더듬 상황에서 직업 관련 말하기 요구량이 높은 직업군은 낮게 추천한 반 면, 직업 관련 말하기 요구량과 교육 수준 정도가 모두 낮은 직업군은 높게 추천되었다. 또한 의사소통 평정에 있어 실험조건 간 유의한 차이가 나타났지만, 의미 차이 평정에 있어서는 차이가 나타나지 않았다. 직업 추천 정도와 관 련해 직업 관련 말하기 요구량 인식 정도는 유의한 수준에서 부적 상관관계가, 의사소통 평정은 유의한 수준에서 정적 상관관계가 나타났다. 또한, 의미 차이 평정에 있어서도 유의한 수준에서의 정적 상관관계가 나타났다. 이는 의사소통장애인으로서 말더듬 성인이 직업과 관련해 상당한 역할 제한성을 가지고 있음을 보여주는 결과라 할 수 있다.
\end{abstract}

핵심어: 말더듬, 직업 추천, 직업상담사, 역할 제한성

\section{참고문헌}

김향희. (1996). 운동실조형 마비성 구음장애에 적용되는 지각적, 음향학적, 생리학적 도구에 관하여: 환자사례를 중심으로. 제 2회 음성학 학술대회자료집(pp. 68-71).

박진, 오선영, 전제표, 강진석. (2015). 배경소음상황에 따른 성인 말더듬화자의 발화 관련 변수 비교. 말소리와 음성과학, 7(1), 27-37.

심현섭. (2000). 한국 말더듬 성인에 대한 고정관념 연구. 언어청 각장애연구, 5(1), 192-208.

심현섭, 신문자, 이은주. (2010). 파라다이스 유창성 검사II (P-FA-II). 파라다이스복지재단.

유길상. (2017). 4차 산업혁명시대의 직업능력개발정책 - 이행노 동시장 모형을 중심으로. 실천공학교육논문지, 9(2), 167-174. 이승환. (2005). 유창성장애. 서울: 시그마프레스.

전희숙, 전효은. (2015). 말더듬 성인의 비유창성군의 특성. 언어
치료연구, 24(1), 135-144.

한국고용정보원. (2015). 한국직업전망서. (https://www.keis.or. $\mathrm{kr} / \mathrm{user} / \mathrm{extra} / \mathrm{main} / 2108 /$ publication/publicationOnlyList/jsp/ LayOutPage.do? categoryIdx $=125 \&$ pubIdx $=5191 \&$ column $=\&$ search $=\&$ spage $=2 \#$ totalList $)$

* 이 논문은 2017년 대한민국 교육부와 한국연구재단의 지원을 받아 수행된 연구임 (NRF-2017S1A5A8018870). 본 연구에 참여해주신 모든 직업상 담사 선생님들께 감사드립니다. 